\title{
Carlo i Francesco Ceroniowie w świetle nowych źródeł archiwalnych
}

$\mathrm{W}$ 2. połowie XVII w. do Warszawy przybyła grupa architektów pochodzących z położonej nad jeziorem Lugano Valsoldy, w północnej Lombardii. Wśród nich znaleźli się Ceroniowie. W stolicy pracowali architekci, bracia Giovanni Battista i Domenico oraz spokrewnieni z nimi, również bracia - Carlo i Francesco. O ile dwaj pierwsi to postacie dość enigmatyczne, o których nie mamy zbyt wielu informacji ${ }^{1}, \mathrm{o}$ tyle Carlo i Francesco stali się lepiej znani dzięki badaniom Mariusza Karpowicza. To on odnalazł ich metryki w archiwum parafialnym w Albogasio Inferiore, ustalił koligacje rodzinne, dotarł do kontraktu Francesca Ceroniego na prace przy kościele sakramentek oraz do testamentu Carla Ceroniego. Wszystkie te odkrycia źródłowe Karpowicz zamieścił w książce Artisti Valsoldesi in Polonia nel '600 e ‘700, w której poświęcił Ceronim jeden z rozdziałów, wydał również o nich osobną publikację (nakładem Comune di Valsolda), a dziesięć lat później jej polską wersję (przy wsparciu Urzędu Gminy w Węgrowie $)^{2}$.

Na użytek Słownika architektów i budowniczych środowiska warszawskiego XV-XVIII wieku przeprowadzono kwerendę w archiwach parafialnych Valsoldy, Archiwum Państwowym w Como oraz Archiwum Głównym Akt Dawnych w Warszawie. Zaowocowała ona odnalezieniem nowych źródeł na temat interesujących nas architektów, ale leksykograficzny charakter biogramów zawartych w Słowniku ${ }^{3}$ nie pozwolił na przedstawienie nieznanych dotąd informacji w szerszym kontekście.

Z testamentu Carla Ceroniego wynika, że głównym spadkobiercą majątku został jego młodszy brat Francesco. Przebywająca we Włoszech żona Carla, Caterina Berrera, miała dożywotnio pozostać w dobrach w Albogasio. W dokumencie pojawia się zapis doprecyzowujący rozporządzenia spadkowe na wypadek bezpotomnej śmierci Francesca. Jak to opisał Mariusz Karpowicz: „,w przypadku gdyby Franciszek nie ożenił się lub ożeniwszy

\footnotetext{
${ }^{1}$ Ostatnio Piotr ŁUGOWSKI, „Ceroni Giovanni Battista”, [w:] Słownik architektów i budowniczych środowiska warszawskiego XV-XVIII wieku, red. Piotr MIGASIEWICZ, Hanna OSIECKA-SAMSONOWICZ, Jakub SITO, Warszawa 2016, s. 94-96; id., „Ceroni Domenico”, [w:] Stownik architektów i budowniczych środowiska ..., s. 91-92.

${ }^{2}$ Mariusz KARPOWICZ, Artisti Valsoldesi In Polonia nel '600 e '700, Valsolda 1996, s. 96-105; id., Carlo e Francesco Ceroni - architetti valsoldesi In Polonia, Valsolda 1998; id., Carlo i Francesco Ceroni - budowniczowie kościołów w Węrowie, Węgrów 2008.

3 Piotr ŁUGOWSKI, „Ceroni Carlo”, [w:] Stownik architektów i budowniczych środowiska ..., s. 87-91; id., „Ceroni Francesco", [w:] Stownik architektów i budowniczych środowiska ..., s. 92-94.
} 
się nie miał dzieci - rozkazał Carlo całą resztę spuścizny spieniężyć i równo rozdzielić miedzy ludność Albogasio, z wykluczeniem jednak rodziny Farina, istniejącej zresztą na miejscu do dziś. Nie dojdziemy już dzisiaj, jakie to żale powodowały taką pamiętliwą niechęć testatora dla tej rodziny"4. Kwerenda w archiwum parafialnym w Albogasio ujawniła źródła pozwalające na wyjaśnienie tej zagadki. Najwcześniejszym z dokumentów jest wystawiony 11 grudnia 1711 r. w Urzędzie Starego Miasta Warszawy akt ustanowienia pełnomocników. Carlo Ceroni, budowniczy jego Królewskiej Mości, stawiwszy się w tym urzędzie mianował plenipotentami dwóch braci Bellottich - Pietra Martiriego oraz Carla Antonia. Aktem tym zezwolił, aby „w sprawie sprzedaży, jak i w sprawie kupna wszelakich dóbr procedować i traktować zgodnie z interesem zeznającego, wyliczać sumy pieniężne, podejmować, kwitować z podjętych, nakładać i zwalniać areszty oraz czynić i przeprowadzać inne rzeczy, które wydadzą im się zgodne z interesem ustanawiającego, a także ustanawiać na swoje miejsce innych plenipotentów z mocą podobną lub ograniczoną [...] cokolwiek ciż plenipotenci lub ich zastępcy uczynią lub przeprowadzą w imieniu ustanawiającego, on uzna to za uczynione i słuszne"6. Dokument ten został wysłany bądź przywieziony do Albogasio. Nazwisko Pietra Martiriego Bellottiego jako adwokata Ceroniego pojawia się dwa lata później w liście Carla Fariny do ówczesnego burmistrza Valsoldy - Fontany, nieznanego z imienia ${ }^{7}$. Do listu, pisanego pod koniec 1713 r., załączony został zbiór rachunków zatytułowany Coppia del libro del Signore Carlo Farina fatto in Milano li 29 maggio 1712, które dotyczą bezpośrednio Carla Ceroniego - syna Giacomo z Albogasio. Spisane na siedmiu stronach rachunki pojawiają się jako dowód w sprawie prowadzonej przed burmistrzem przeciw Ceroniemu ${ }^{8}$. Farina wskazuje w liście, że Ceroni winny był mu kwotę 3779 lirów mediolańskich za rachunki prowadzone dla niego od 17 marca 1693 do lipca 1699 r. W tym okresie miał otrzymać od Ceroniego 3740 lirów. Architekt pozostawał mu więc dłużny ponad 39 lirów i tę właśnie kwotę Farina próbował wyegzekwować. Nie sposób przywołać wszystkich rachunków, warto zaznaczyć, że część z nich obejmowała zakupy towarów o różnym charakterze, od podstawowych materiałów spożywczych po wydatki na ubiory oraz sprzęty domowe. Odnotowano w nich także wielokrotne przekazywanie pieniędzy dla małżonki Ceroniego oraz wypłaty określonych sum według wskazania - przypuszczalnie listowego - architekta. Pojawiają się też nazwiska kuzynów z rodziny Bellotti i Pagani oraz osób z kręgu znajomych architekta. Na ostatniej stronie wyszczególniono kwoty, które Ceroni przekazywał Farinie z Warszawy za pośrednictwem różnych osób na poczet spłaty zaciągniętych długów. Najwięcej wpłat dokonał w 2. połowie 1693 r., czyli już po ukończeniu budowy kościoła kapucynów w Warszawie. Wśród osób przekazujących pieniądze znaleźli się nie notowani wcześniej Bernardo Bernardis i Gaudencio Dragoni. Pojawia się też nazwisko znanego warszawskiego budowniczego Rocca Solariego, który 20 listopada osobiście dostarczył przekazaną przez

\footnotetext{
${ }^{4}$ KARPOWICZ, Carlo i Francesco Ceroni - budowniczowie ..., s. 13.

${ }^{5}$ Być może tożsamy z Pietro Martirim Bellottim, architektem działającym w Rzeszowie na usługach Stanisława Herakliusza Lubomirskiego, budowniczym kościoła bernardynów wg projektu Tylmana van Gameren, ojcem Jana Chrzciciela Bellottiego.

${ }^{6}$ Valsolda, Albogasio Inferiore, archiwum parafialne [dalej Valsolda, Albogasio], pudło nr 3, Plenipotencja Carla Ceroniego z 11 XII 1711, dokument luzem (tłum. i red. tekstu oryginalnego Tomasz Płóciennik). Zob. Aneks.

${ }^{7}$ Valsolda, Albogasio, pudło nr 3, List Carla Fariny do burmistrza Valsoldy z 1713 r., luźny poszyt.

${ }^{8}$ Valsolda, Albogasio, pudło nr 3, Coppia del libro del Signore Carlo Farina fatto in Milano li 29 maggio 1712, rachunki wpięte w poszyt.

${ }^{9}$ Ibid.
} 
1. Coppia del libro del Signore Carlo Farina fatto in Milano li 29 maggio 1712, Valsolda, Albogasio Inferiore, archiwum parafialne, pudto $\mathrm{nr}$ 3, nlb.

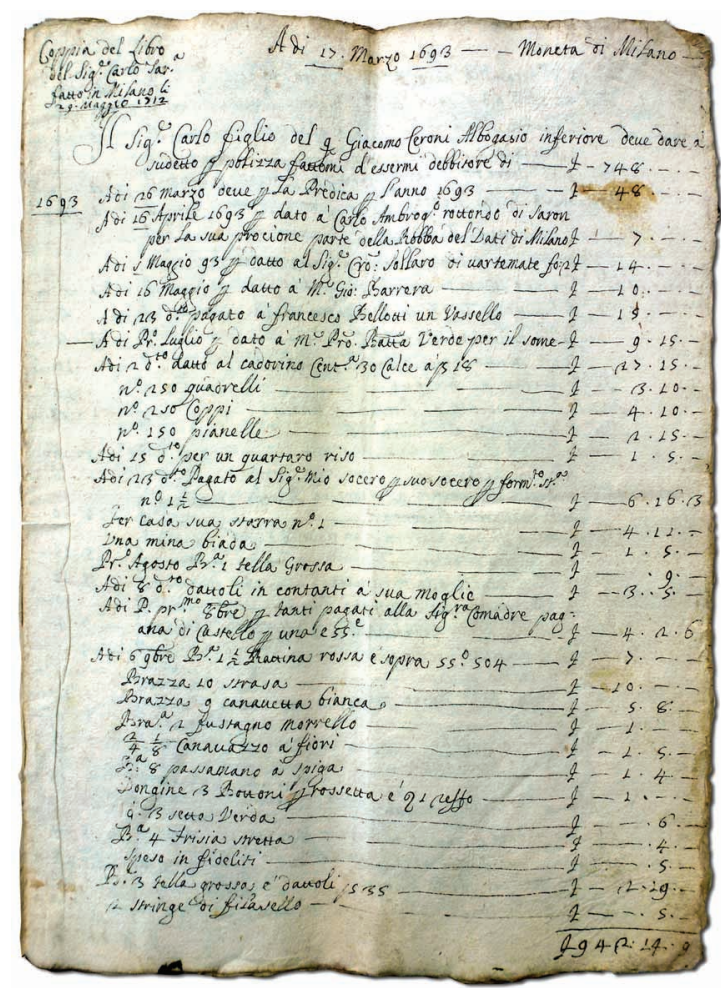

Ceroniego kwotę 100 dukatów ${ }^{9}$. Warto dodać, że Rocco Solari za pośrednictwem Fariny przekazywał z Polski pieniądze swojej rodzinie mieszkającej w Cureglii k. Lugano ${ }^{10}$. List Fariny burmistrz Valsoldy sygnował 3 stycznia 1714 r. ${ }^{11}$ Sprawa wspomnianego długu wielokrotnie przewija się w korespondencji, o czym świadczy list pisany z Warszawy

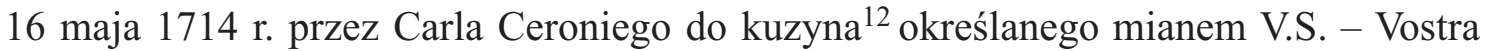
Signoria; z dużą dozą prawdopodobieństwa można stwierdzić, że chodziło o ówczesnego burmistrza Valsoldy, czyli Fontanę (na koligacje rodziny Ceroni z Fontanami wielokrotnie zwracał uwagę Mariusz Karpowicz). We wspomnianym liście Ceroni ustosunkował się do zarzutu jakoby Farina, jeszcze przed wyjazdem architekta do Polski, przekazał mu 176 lirów tytułem zaliczki za konia. Zarzucił Farinie kłamstwa i krzywoprzysięstwo, pisząc: „O Boże, można dawać tak podłe kłamstwa? Jestem gotów złożyć najbardziej uroczystą przysięgę, tak odczuwalną, jakiej się nie czyni; to jest, że nie otrzymałem nawet czwartej części zaliczki za konia, zanim odszedłem"13.

\footnotetext{
${ }^{10} \mathrm{Na}$ kartach księgi rachunkowej rodziny Solari w Cureglii (prowadzonej przez Agnese Solari, wdowie po Girolamie Solarim) wielokrotnie odnotowano otrzymanie pieniędzy wysyłanych z Polski przez Rocca Solariego za pośrednictwem Fariny. Rachunki z lat 1702-1712 wskazuja, że sumy te były przeznaczone na podatki i taksy za nieruchomości w Cadempino, Lamone i Cureglii koło Lugano, na bieżące koszty prowadzenia gospodarstwa, a także na intencje mszalne w kościele św. Krzysztofa w Cureglii. Zob. Cureglia, archiwum parafialne, Nota della spesa e del ricavo de fruti della famiglia Solari, s. 7, 10. Księga rachunkowa opublikowana przez Graziano TARILLI, Aspetti di vita settecentesca nella campagna luganese da un libro dei conti inedito, Basilea 1982, s. 23, 25. Zob. także Piotr ŁUGOWSKI, „Solari Rocco", [w:] Słownik architektów i budowniczych środowiska warszawskiego..., s. 441-443.

${ }^{11}$ Valsolda, Albogasio, pudło nr 3, List Carla Fariny do burmistrza Valsoldy z 1713 r., luźny poszyt.

12 Valsolda, Albogasio, pudło nr 3, List Carla Ceroniego do burmistrza Valsoldy z 16 maja 1714 r., luźne karty. List odnosi się do listu z dnia 18 kwietnia, otrzymanego właśnie od Fontany. Poza rachunkami wymienianymi w artykule, w ramach zespołu źródeł (pudło nr 3), zachowały się liczne szczątkowe rozliczenia, które wywołują niejasności i utrudniają określenie wysokości całego długu.

${ }^{13}$ Ibid., (thum. autor).
} 
Pozostawiając na marginesie emocjonalne skargi i pretensje Ceroniego, warto poświęcić nieco uwagi wplecionym w tekst informacjom na temat współpracy architekta z rodziną Farina. Poza zabezpieczaniem finansowym włoskich interesów Ceroniego, Farina realizował dla niego różne zamówienia, m.in wysłał z Wenecji skrzynię kupiecką zawierającą 25 egzemplarzy Libri di Thriaca przeznaczonych dla nieznanego z imienia Bertiniego ${ }^{14}$. Chodzi tu o powstające od XV do XVIII w. księgi, wzorowane na spisanym przez lekarza Nerona traktacie Teriaca di Andromaco, które instruowały, jak przygotować mikstury przeciwdziałające wszelkim truciznom. Tego rodzaju publikacje z dziedziny ziołolecznictwa i alchemii były popularne także w Polsce ${ }^{15}$. W tym samym liście Ceroni opisał, w jaki sposób pomagał rodzinie Fariny, zwłaszcza jego bratu, Giacomo, który przebywał w Warszawie i wykonywał różne prace budowlane. Ponoć Giacomo nie podołał swoim obowiązkom i został zwolniony przez Giuseppe Simone Bellottiego ${ }^{16}$. Pozbawiony środków do życia, zwrócił się o pomoc do Carla Ceroniego, który, jak sam podkreślał, z wielkim zaangażowaniem, nie szczędząc czasu, zabiegał o posadę dla Giacoma, choć ten nie znał języka, ani nie miał odpowiednich kwalifikacji. Ostatecznie, pomimo tych niedostatków, Ceroniemu udało się załatwić Farinie pracę za 100 dukatów rocznie przy jednej z fundacji Jana III Sobieskiego. Najprawdopodobniej chodziło o budowany w latach 1685-1693 kościół kapucynów przy ul. Miodowej lub o klasztor tego zakonu, Ceroni był bowiem głównym konduktorem tej budowy nadzorującym ponad 60 robotników ${ }^{17}$.

Wspomniany list rzuca nowe światło na kwestię potomstwa Ceroniego. Na podstawie badań Mariusza Karpowicza wiemy, że architekt z żoną Cateriną (poślubioną 28 stycznia 1674) miał córkę Lucię Cecilię Anastasię (27 IX 1680 - 24 IV 1682) zmarłą jako dziec$\mathrm{ko}^{18}$. Rok po jej śmierci, w 1683 r. parze urodziła się druga córka, której nadano te same imiona i która, wbrew przypuszczeniom Karpowicza, dożyła pełnoletniości ${ }^{19}$, ponieważ w liście pojawia się kwestia posłania samotnej 31-letniej już Lucii do klasztoru w Lugano, aby zapewnić jej odpowiednie warunki życia. Z zapisów w księgach metrykalnych wynika, że córka Ceroniego zmarła 9 października 1717 r. (trzy lata po wstąpieniu do klasztoru) i pochowana została w kościele Santa Maria Annunziata w Albogasio ${ }^{20}$.

\footnotetext{
${ }^{14}$ Valsolda, Albogasio, pudło nr 3, List Carla Ceroniego do burmistrza Valsoldy z 16 maja 1714 r., luźne karty. Chcąc zaoszczędzić na przesyłce, Farina miał umieścić w skrzyni z cennymi woluminami 2 ciężkie matryce do wykonywania hostii, przeznaczone dla jego brata Giacoma, który wówczas przebywał w Warszawie. Z powodu długiej podróży i znacznego obciążenia 8 egzemplarzy traktatu uległo zniszczeniu, a Ceroni nie otrzymał żadnych wyjaśnień. Jak wskazywał w liście, przesyłka kosztowałaby Farinę minimum 4 talary, podczas gdy pojedyncza księga traktatu sprzedawana była wówczas w Warszawie po 10 lirów mediolańskich. Wedle rachuby architekta, w ramach rekompensaty za poniesioną szkodę, Farina był mu winien 105 lirów.

15 Zakup takiej księgi odnotowano w rachunkach klasztoru kamedułów warszawskich w styczniu 1696 roku. Zob. Archiwum Archidiecezjalne w Warszawie, rkps 437, sygn. Top. A.X 1.60: Liber expensorum 1693-1756, s. 51.

${ }^{16}$ Niewykluczone, że chodzi o prace przy kościele misjonarzy pw. św. Krzyża na Krakowskim Przedmieściu, wznoszonym w latach 1679-1696. Bellotti był jego głównym projektantem i budowniczym. Zob. Jakub SITO, „Historia fundacji i budowy kościoła św. Krzyża”, [w:] Serce Miasta. Kościół św. Krzyża w Warszawie, red. Kazimierz SZTARBAŁŁO, Michał WARDZYŃSKI, Warszawa 2010, s. 146-149.

${ }^{17}$ Valsolda, Albogasio, pudło nr 3, List Carla Ceroniego do burmistrza Valsoldy z 16 maja 1714 r., luźne karty. W liście wspomina: „in quel tempo avevo piu di 60 artesani che lavorava sotto di me”. Dalej Ceroni wskazuje, że Giacomo Farina wielokrotnie mieszkał u niego w domu i spożywał z nim posiłki, za co należało mu się 419 lirów.

18 Valsolda, Albogasio, archiwum parafialne, Liber baptizatorum 1639-1818, nlb; Morti 1666-1818, nlb. Zob. także: KARPOWICZ, Artisti Valsoldesi..., s. 96.

${ }^{19}$ Mariusz Karpowicz wskazał, że obie córki Ceronich zmarły niedługo po urodzeniu. Zob: KARPOWICZ, Artisti Valsoldesi..., s. 96; KARPOWICZ, Carlo e Francesco Ceroni architetti..., s. 7.

${ }^{20}$ Valsolda, Albogasio, Morti 1666-1818, nlb.
} 


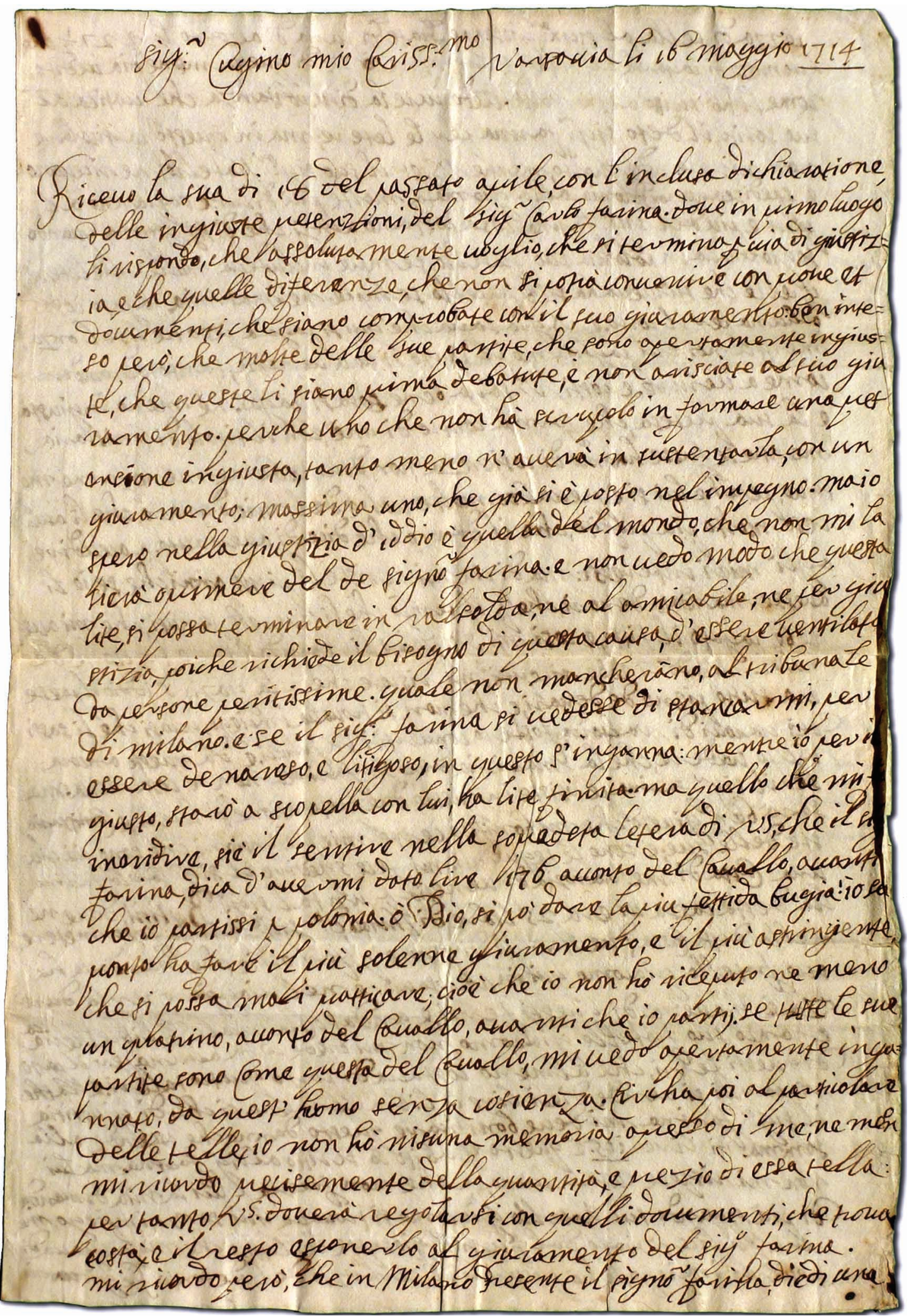

2. List Carla Ceroniego do burmistrza Valsoldy z 16 maja 1714 r. (fragm.)

Valsolda, Albogasio Inferiore, archiwum parafialne, pudło $\mathrm{nr} 3$, nlb. 
Pod koniec listu Ceroni wymienia nazwiska trzech osób, którym faktycznie był coś dłużny, nie ma wśród nich oczywiście Fariny. Zwraca uwagę zobowiązanie do spłaty 500 lirów spadkobiercom zmarłego w 1705 r. Carla Martina Fontany z Castello - dziadka Paola Antonia Fontany, architekta działającego na terenie Rzeczypospolitej ${ }^{21}$. Jest to kolejny dowód na bliskie relacje łączące Ceronich z rodziną Fontanów.

Konflikt między Carlem Fariną a Ceronim nie zakończył się przed burmistrzem Valsoldy, trafił do sądu w Mediolanie ${ }^{22}$. Ostatecznego rozstrzygnięcia tej sprawy nie udało się odszukać. Emocjonalny zatarg z Fariną wyjaśnia niechęć testatora do tej rodziny.

Niewykluczone, że Carlo Farina mógł odgrywać znaczną rolę dla Włochów z warszawskiego środowiska architektonicznego przełomu XVII/XVIII w. Jak wskazano, był on osobą, której dostarczano pieniądze wysyłane z Polski nie tylko dla rodziny Ceronich, ale także Solarich. Może tego rodzaju usługi świadczył innym włoskim rzemieślnikom znad jeziora Lugano przebywającym w Warszawie.

Ciekawych materiałów na temat Carla Ceroniego dostarczyła również kwerenda w Archiwum Głównym Akt Dawnych w Warszawie, podczas której odnaleziono sześć listów tego architekta odnoszących się do prowadzonych przez niego prac przy budowie kościołów w Węgrowie ${ }^{23}$. Ich adresatem był przebywający w Krasnym Dworze ${ }^{24}$ ówczesny ekonom i administrator generalny dóbr wojewody płockiego Jana Dobrogosta Krasińskiego - Samuel Pączowski. Najwcześniejsze dwa listy z tego zbioru pochodzą z maja 1715 r., kiedy Ceroni prowadził prace budowlane przy klasztorze reformatów. Architekt pośredniczył wówczas w sprowadzeniu kamienia do „galerii OO. Reformatów”, przeznaczonego zapewne do klasztornych krużganków. Zamówiono go u Antoniego Baya - warszawskiego kamieniarza i przedsiębiorcy budowlanego, bliskiego krewnego architekta Carla Antonia Baya $^{25}$. Pozostałe listy dotyczą głównie domagania się należności za wykonane prace. W liście z października 1716 r., architekt prosi o przekazanie 300 tymfów ${ }^{26}$. W trzech kolejnych pisanych już po śmierci Jana Dobrogosta Krasińskiego (zm. 21 II 1717) Ceroni tłumaczy jego administratorowi, dlaczego poniósł przy budowie tak wysokie koszty. W najwcześniejszym z nich odnosi się do listu otrzymanego od Pączowskiego: ,piszesz do mnie taki list wiedząc dobrze co ja za szkodę miał budując i burząc, co JWMPan Wojewoda ś. p. obiecał mi kompensować, a dotychczas nic nie widzę. Suplikuje tedy pokornie do łaski WMPana abyś mnie w swej łasce miał i protekcji, i u WMPani Starościny wyjednał to abym pieniądze moje odebrał, a ja obliguje się tam jechać dla skończenia tylko niech mam pierwy co mi należy bo jest wielce potrzebne [...]"27. Określenie „,budując i burząc", użyte tu przez Ceroniego, sugeruje wielokrotne zmiany w projekcie, a także znaczne przekształcenia wzniesionych już fragmentów skrzydła budynku klasztornego. Niewykluczone, że sam Ceroni na etapie wykonawczym korygował projekt. W liście, da-

\footnotetext{
${ }^{21}$ Valsolda, Albogasio, pudło nr 3, List Carla Ceroniego do burmistrza Valsoldy z 16 maja 1714 r., luźne karty. Józef SKRABSKI, Paolo Fontana. Nadworny architekt Sanguszków, Tarnów 2007.

${ }^{22}$ Valsolda, Albogasio, pudło nr 3, luźne karty.

${ }^{23}$ Warszawa, Archiwum Główne Akt Dawnych (dalej AGAD), Nabytki Oddziału III, sygn. 31. Zob. Aneks.

24 Taką nazwę nosiła wówczas należąca do Krasińskich miejscowość Stara Wieś pod Węgrowem. Za zwrócenie uwagi na ten fakt pragnę podziękować Romanowi Postkowi.

${ }^{25}$ AGAD, Nabytki Oddziału III, sygn. 31, Listy Carla Ceroniego do Samuela Paczowskiego z 3 i 10 V 1715, s. 168, 170. Odnośnie prac Antoniego Baya zob. Jakub SITO, „Bay Antoni”, [w:] Słownik architektów i budowniczych środowiska..., s. 36-37.

${ }^{26}$ AGAD, Nabytki Oddziału III, sygn. 31, List Carla Ceroniego do Samuela Paczowskiego z 9 X 1716, s. 173-174. Wzmiankowany jest w nim bliski współpracownik Ceroniego, nieznany z nazwiska Dominik.

${ }^{27}$ AGAD, Nabytki Oddziału III, sygn. 31, List Carla Ceroniego do Samuela Paczowskiego z 19 VIII 1717, s. 178-179.
} 
3. Zgoda z JM Panem Franciszkiem

Ceronim o dachówkę do fary wydawaną do

Węgrowa, Archiwum Glówne Akt

Dawnych, Nabytki Oddziatu III, sygn 31, s. 23

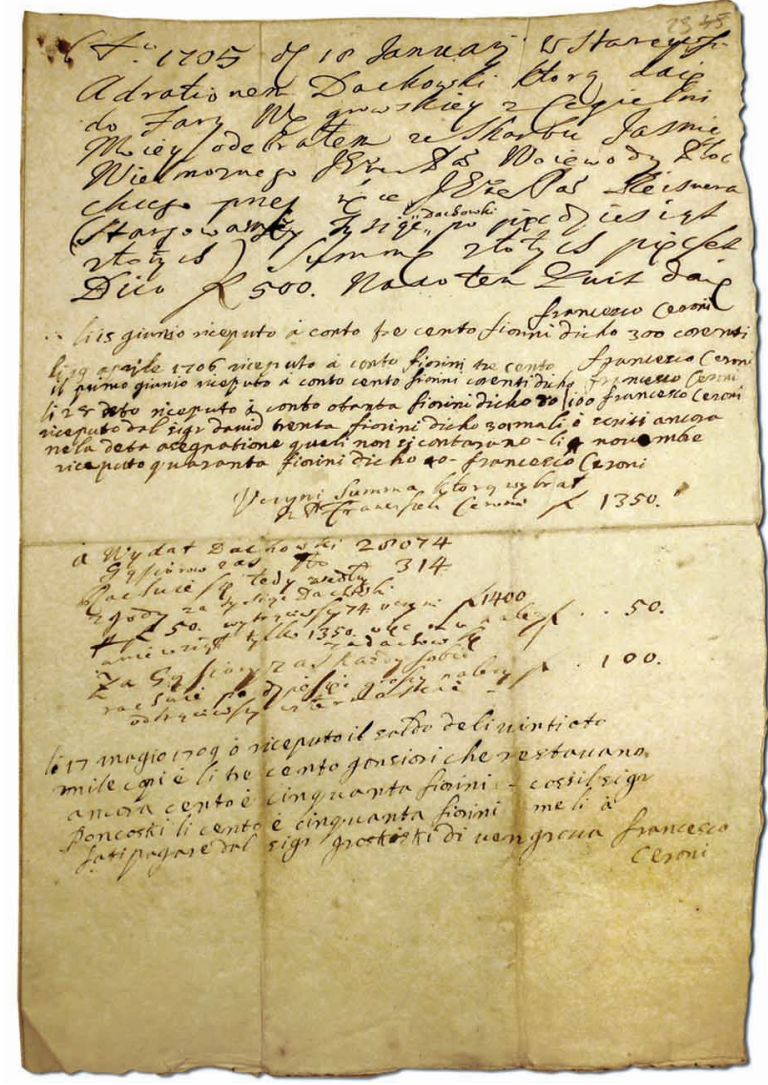

towanym na 10 września 1717 r., architekt ponownie wspomina o przekształceniach dokonywanych podczas budowy, tłumaczy się również z zarzutu nieukończenia prac: „Jam kilka razy pisał do WMPana upraszając WMPana abyś mi posłał regestr co mi jeszcze należy od WMPaństwa a nie mogę tej łaski otrzymać od WMPana. Piszesz mi WMPan, że nic nie wezmę póki nie skończę wszystkiego u oo. Reformatów, czyli to nie jest wiadomo WMPanu, że ja wszystko dawno już zakończył i jak wiele w tym miałem szkody murując i burząc, a o tym nic WMPan nie wspomnisz, ja się nie wymawiam jechać i upewniam, że pojadę ale pierwy chce być upewniony, że zastanę pieniądze mnie należące złożone u OO Reformatów [...]"28. Ostatni list z 21 września 1717 r. po części rozwija poprzednie wątki. Porównuje także prace wykonane w Węgrowie do prac prowadzonych przy klasztorze warszawskich kapucynów. Dla wzmocnienia swojej argumentacji Ceroni wykazuje troskę o pozagrobowe udręki zmarłego fundatora: ,[... ] JMWPan Dobrodziej ś.p. dla zatrzymania tego mego cierpieć będzie w czyśćcu i póty póki mnie WMPaństwo mnie nie uspokoicie. Wierzę WMPan jakoś za żywota był życzliwy Panu swemu tak i teraz miej pożałowanie nad nim i nad dusząjego, a mnie uspokoić staraj się WMPan gdyż te funkcje które WMPaństwo czynicie nie będą taką pomocą duszy Jego jako to kiej WMPaństwo oddacie co komu należy gdyż ci co im należy wcale, że pomsty do Boga wołają. Jak jakiem był życzliwy Sługa JMci Dobrodziejowi ś.p. za żywota tak i teraz jestem i dlatego dotychczas anim wołał pomsty anim wołam ale się obawiam aby mnie ciężka potrzeba do tego nie stymulowała. Suplikuje pokornie przeczytać ten list mój dobrze i zrozumieć go a wiem, że się WMPan uratujesz nad duszą Pana swego ś.p. i nad potrzebą moją"29.

${ }^{28}$ AGAD, Nabytki Oddziału III, sygn. 31, List Carla Ceroniego do Samuela Paczowskiego z 10 IX 1717, s. 176.

${ }^{29}$ AGAD, Nabytki Oddziału III, sygn. 31, List Carla Ceroniego do Samuela Paczowskiego z 21 IX 1717, s. 162-165. 
Zachowana korespondencja wskazuje, że prace przy zespole reformackim w Węgrowie, nie zakończyły się, jak zwykło się dotąd uważać, z chwilą ukończenia budowy kościoła w $1706 \mathrm{r}^{30}[\ldots]$ Wynika z niej, że budowa klasztoru trwała jeszcze w 2. dekadzie XVIII w. Zagadnieniem wartym przebadania jest kwestia etapów budowy całego zespołu. Pojawienie w źródłach związanych z Węgrowem nazwiska warszawskiego kamieniarza i przedsiębiorcy budowlanego Antoniego Baya pozwala jeszcze silniej wiązać węgrowską świątynię ze środowiskiem stołecznym, już nie tylko pod względem projektu i nadzoru, ale także wykonawstwa oraz pochodzenia materiałów.

W tym samym zbiorze Archiwum Głównego Akt Dawnych odnaleziono jeszcze inne dokumenty dotyczące prac budowlanych w Węgrowie. Są to pokwitowania Francesca Ceroniego za dachówkę do kościoła farnego ${ }^{31}$. 18 stycznia 1705 r. Ceroni skwitował odbiór $500 \mathrm{złp} \mathrm{(po} 50 \mathrm{zł}$ za tysiąc sztuk). W przekazaniu pieniędzy ze skarbca wojewody pośredniczył marszałek dworu Krasińskich, malarz, architekt i geometra Jan Reisner. Rachunek został uzupełniony o zapisy kolejnych sum za dachówkę i gąsiory, które Francesco otrzymał w następnych latach. Łącznie na potrzeby fary węgrowskiej Ceroni wydał ze swojej cegielni 28074 sztuk dachówki oraz 314 gąsiorów, za co otrzymał 1350 złotych. Ostatnie pokwitowanie odbioru pieniędzy (w języku włoskim) datowane jest 17 maja 1709 r. $^{32}$ Odnalezione dokumenty wykazują interesującą zbieżność. Jak wiadomo Ceroniowie dostarczali materiały budowlane do wielu „fabryk” warszawskich. Najwcześniejsze zapisy źródłowe pochodzące z lat 1707 i 1709 dotyczą wypłat za cegłę, kamień na gzyms oraz dachówkę przeznaczoną do kierowanej przez Francesca Ceroniego budowy kościoła paulinów na Nowym Mieście ${ }^{33}$. Kolejne wzmianki o sprzedaży materiałów budowlanych (cegły i dachówki) dotyczą prac z lat 1713-1721 prowadzonych przez Carla Antonia Baya przy przebudowie pałacu Adama Mikołaja Sieniawskiego przy Krakowskim Przedmieściu. Na wszystkich dokumentach sprzedaży występuje z imienia jedynie Francesco $^{34}$. Jemu również 24 kwietnia 1717 r. asygnowano wypłatę ,za 5800 sztuk dachówki po 100 za tysiąc",przeznaczonych dla budowanego klasztoru misjonarzy przy Krakowskim Przedmieściu ${ }^{35}$. W maju 1719 r., kiedy Francesco Ceroni dzierżawił cegielnię na Mokotowie, on i zatrudniony przez niego strycharz Dominik Kraskiewicz zostali pozwani przez ówczesnego wójta tej wsi, a zarazem znanego architekta Augustyna Locciego ${ }^{36}$, o czym dowiadujemy się z Ksiag Sadu Referendarskiego. Powodem był prowadzony na

\footnotetext{
${ }^{30}$ Mariusz Karpowicz podaje, że murowany klasztor ukończono w 1693 r., budowę kościoła zaś w 1706, zgodnie z inskrypcją na fasadzie. zob. Mariusz KARPOWICZ, Cuda Węgrowa, Węgów 2009, s. 85-86; id., Carlo i Francesco Ceroni-budowniczowie..., s. 11.

${ }^{31}$ AGAD, Nabytki Oddziału III, sygn. 31, Zgoda z JM Panem Franciszkiem Ceronim o dachówkę do fary wydawanq do Wegrowa, s. 23.

32 Ibid., Najnowszy stan badań na temat Reisnera przedstawił Paweł MIGASIEWICZ, „Reisner Jan”, [w:] Słownik architektów i budowniczych środowiska..., s. 382-384.

33 Jakub Sito wskazał na Francesca Ceroniego jako konduktora budowy. Wcześniejsza literatura wiązała budowę z Carlem Ceronim. Zob. Jakub SITO, „«Fabryka »kościoła pw. Św. Ducha w Warszawie w latach 1707-1730 w świetle źródeł paulińskich - przebieg prac, projektanci, wykonawcy", [w:] Ex voto. Studia dedykowane Ojcu Janowi Golonce OSPPE $w$ 75. rocznice urodzin $i w 50$. rocznicę święceń kapłańskich, red. Przemysław MROZOWSKI, Jerzy ŻMUDZIŃSKI, Częstochowa 2012, s. 355-400.

${ }^{34}$ Kraków, Biblioteka Książąt Czartoryskich, rkps 11301, Regestr Pieniędzy wydanych na rożne potrzeby do reparacyi Pałacu Warszawskiego ..., s. 7, 8, 12, 13; rkps 11302, s. 2, 50, 61-64, 72, 76, 78, 89, 91, 100.

35 Warszawa, Archiwum Narodowego Instytutu Dziedzictwa, Teki Łopacińskiego 123/III, Diarium Procurae Domus Varsaviensis Crucis P. Mission.1716-1745, k. 3r.

${ }^{36}$ Hanna OSIECKA-SAMSONOWICZ, „Locci Augustyn Wincenty”, [w:] Słownik architektów i budowniczych środowiska..., s. 291.
} 
terenie cegielni, nielegalny wyszynk, do którego uprawniona była jedynie karczma wójtowska. Sąd nakazał, aby „w pomienionej cegielni na szkodę urodzonego wójta mokotowskiego pod jakimkolwiek pretekstem tak przez się jako i subordynowane osoby piwa i gorzałki szynkować nie ważyli się [...]". Ceroni został uwolniony od bezpośrednich zarzutów. Otrzymał jednak nakaz ukrócenia procederu na terenie cegielni oraz dopilnowania przestrzegania zakazu wśród swoich pracowników: „Co do osoby szlachetnego Ceroniego wspólnie ex fundo colonario pozwanego. Ponieważ tenże pozwany szlachetny Ceroni żeby za rozkazaniem i wiadomością swoją w cegielni w posesji swojej zostającej szynkowano neguje ani sobie szynku pretenduje, strona też powodowa skargi swojej onemu nieprobuje. Dlatego go do sprawy i imetycyi urodzonego powoda uwalnia. Jednak ażeby tenże szlachetny Ceroni podczas swojej posesji piwa i gorzałki robić i szynkować w tejże swojej cegielni pod jakimkolwiek pretekstem strycharzowi i robotnikom swoim nie pozwalał, i owszem zakazał i na potym zabraniał onemu i którykolwiek napotym tejże cegielni posesorom pod winą banicji wiecznej która ex nunc na nich wskazuje się..."37.

Abstrahując od opisanych wyżej, nielegalnych praktyk, można przypuszczać, że dzierżawiona przez Francesca Ceroniego cegielnia nie była jedyną, jaką zarządzał lub posiadał. Wszystkie przywołane wyżej źródła prowadzą do wniosku, że to młodszy brat Carla Ceroniego odgrywał ważniejszą rolę w prowadzonym przez nich przedsiębiorstwie budowlanym. Pośrednio wskazuje na to przywoływany wyżej list Carla z maja 1714 r., w którym stwierdza on, że brat jest od niego zamożniejszy ${ }^{38}$. Pewnie Francesco Ceroni jako magister murarius i rzutki przedsiębiorca uzyskiwał wyższe dochody niż legitymujący się statusem architekta królewskiego, jego starszy brat Carlo.

Po śmierci Carla Ceroniego w 1721 r. Francesco spieniężył swoje stołeczne dobra i powrócił do Albogasio, gdzie jako główny spadkobierca majątku brata starał się zrealizować jego testament. Miał wybudować kaplicę św. Feliksa w miejscu zwanym Redonda, na terenie parafii Albogasio oraz ufundować altarię, dzięki której byłyby regularnie odprawiane msze za duszę Carla. Do budowy jednak nie doszło ze względu na sprzeciw władz diecezjalnych. 4 listopada 1724 r. schorowany Francesco spisał po łacinie testament, w którym część pieniędzy przeznaczył na kaplicę w kościele parafialnym Santa Maria Annunziata, z wymogiem odprawiania pięciu nabożeństw tygodniowo. Egzekutorami swojego testamentu ustanowił kanonika Francesca Ceroniego (syna Hieronima z Albogasio), Carla Isidora Affaitatę i Pietra Martira Bellottiego z San Mamete. Zaznaczył też: „dodaję i dołączam do wyżej wymienionych - z tą samą zdolnością i możliwością - również rzeczonego wielmożnego i wielebnego pana Domenica Antonia Pagana, proboszcza Castello i wikariusza Valsoldy [a także notariusza Kurii w Mediolanie], który razem z rzeczonymi wymienionymi imiennie innymi egzekutorami prowadziłby moje sprawy, i którego proszę i błagam, aby przyjął to zadanie i był współegzekutorem mojego testamentu względem całego mojego dziedzictwa wraz z innymi moimi egzekutorami, także ze zdolnością substytucji innego, także licznych egzekutorów, gdyby go zabrakło lub umarłby, ponieważ taki jest mój zamysł i taka moja wola"39.

\footnotetext{
${ }^{37}$ AGAD, Metryka Koronna, Księgi Saqu Referendarskiego, Ks. Ref. 34, k. 3v-8r.

${ }^{38}$ Valsolda, Albogasio, pudło nr 3, List Carla Ceroniego do burmistrza Valsoldy z 16 maja 1714 r., luźne karty.

${ }^{39}$ Como, Archivio di Stato, Archivio Notarile, Atti dei nottai 3511, Codicillo Francesco Ceroni Albogasio, nlb., (tłum. i red. tekstu oryg. Tomasz Płóciennik). Zob. Aneks.
} 
W sierpniu 1725 wykonawcy testamentu Francesca Ceroniego powołali na pełnomocników „Pana Józefa Rachetta i pana Karola Baya, odpowiednio teścia i zięcia, przebywających w mieście Warszawie - pod ich nieobecność tak jakby w ich obecności - i tak wspólnie, jak i osobno itd., aby jeden niezależnie od drugiego mógł działać[...] ${ }^{40}$ ". Głównym powodem ich powołania była sprawa ściągnięcia należności ze sprzedaży w styczniu 1712 r. warszawskiego domu Carla Ceroniego rodzinie kupców Dominikowi i Zofii Combonim. W źródłach nie udało się odnaleźć śladów aktywności w tej sprawie Carla Antonia Baya, za to działalność Rachettiego została odnotowana; w zachowanym w archiwum parafialnym w Albogasio spisie rachunków prowadzonych przez Domenica Antonia Pagana - proboszcza z Castello i jednego z egzekutorów testamentu - odnajdujemy wypłaty za wysyłkę listów do przebywającego w Warszawie Giuseppe Rachettiego ${ }^{41}$. Korespondencja prowadzona jeszcze w maju 1727 r. dotyczyła zapewne spraw związanych z wyegzekwowaniem długów. Ponadto z rachunków wynika, że u proboszcza z Castello kilkukrotnie pojawiała się (29 listopada 1726; 20 czerwca 1727; 23 lutego, 29 marca, 30 maja 1728) Caterina, wdowa po Carlu Ceronim, której proboszcz wypłacał pewne sumy. Według zapisu w metrykach parafialnych wdowa po architekcie zmarła 17 września $1728 \mathrm{r}$. po piętnastodniowej chorobie. Pochowana została następnego dnia w kościele Santa Anunziata w Albogasio w asyście dziesięciu kapłanów ${ }^{42}$. Jej pogrzeb odnotowany został także w rachunkach Domenica Antonia Pagana ${ }^{43}$.

Carlo i Francesco Ceroniowie dorobili się znacznego majątku, który po ich śmierci przeszedł na własność mieszkańców Albogasio jako Eredita Ceroni. Jeszcze w XIX w. zyski z niego przeznaczane były na potrzeby mieszkańców miasteczka.

\footnotetext{
${ }^{40}$ Como, Archivio di Stato, Archivio Notarile, Atti dei nottai 3566, Procuratio dominorum executorum testamenti nobilis quondam domini Francisci Ceroni in dominum Ioseph Rachettum degentem in civitate Varsaviae - 21 Augusti 1725, nlb., (thum. i red. tekstu oryg. Tomasz Płóciennik).

${ }^{41}$ Valsolda, Albogasio, archiwum parafialne, Nota delle spese spettanti all' Eredita Cerone, luźne karty.

${ }^{42}$ Valsolda, Albogasio, Morturi 1666-1818.

${ }^{43}$ Valsolda, Albogasio, Nota delle spese spettanti all’ Eredita Cerone, luźne karty.
} 


\section{Aneks \\ I \\ Valsolda, Albogasio Inferiore, archiwum parafialne, pudło nr 3, Plenipotencja Carla Ceroniego z 11 XII 1711.}

Actum Varsaviae feria sexta post festum Immaculatae Conceptionis Beatae Mariae Virginis proxima, die undecima mensis Decembris, anno Domini millesimo septingentesimo undecimo.

Coram officio consulari civitatis antiquae Varsaviae actisque eiusdem officii praesentibus personaliter comparens nobilis Carolus Ceroni, aedilis Sacrae Regiae Maiestatis, sanus mente et corpore existens palam, sponte, libere ac per expressum recognovit praesentibusque recognoscit quia ipse nobiles Petrum Martiri et Carolum Antonium de Bellottis fratres inter se germanos, absentes tanquam praesentes, in suos veros, legitimos et indubitatos plenipotentes et mandatarios fecit, constituit et solenniter ordinavit, prout praesentibus facit, constituit et ordinat, dans et concedens iisdem plenipotentibus et mandatariis per se constitutis plenariam facultatem, potestatem et authoritatem coniunctim et divisim, ita ut unus sine alio possint et valeant negotia quaevis sui constituentis cum quibuscunque personis habita et intercedentia peragere et tam in venditione quam etiam in emptione bonorum quorumcunque procedere et tractare interesse sui recognoscentis, summas pecuniarias numerare, levare, de levatis quietare, arresta imponere et relaxare caeteraque quae opportuna ipsis videbuntur ex interesse sui constituentis facere et peragere, alios plenipotentes cum simili vel limitata facultate in locum sui constituere, cavens, quod quidquid iidem plenipotentes sive illorum substituti nomine sui constituentis fecerint, tractaverint et peregerint, pro rato et grato sit habiturus in forma alias plenipotentiae mandati commissi de iure plenissima et perfectissima. Carolo Ceroni.

Ex protocollo actorum officii consularis civitatis antiquae Varsaviae extraditum.

Sebastianus Fabianus Rybczynski

Sacrae Regiae Maiestatis secretarius officii consularis

C. A. Varsaviae notarius manu propria

\section{II}

\section{Como, Archivio di Stato, Archivio Notarile, Atti dei nottai 3511 Codicillus Francisci Ceroni Albogasii (4 XI 1724)}

17244 9-bris

Codicillus Francisci Ceroni Albogasii

[...] mei Iohannis Mariae Pusterlini curiae archipraesulis Mediolani notarii infrasubscripti, parocci Albogasii.

In nomine Domini. Anno a nativitate eiusdem millesimo septingentesimo vigesimo quarto, indictione $2^{\mathrm{a}}$, die sabbati $4^{\mathrm{a}}$ mensis 9 -bris, hora circiter vigesima $2^{\mathrm{a}}$.

Cum ego, Franciscus Ceronus, filius quondam Iacobi Albogasii Vallissolidae dominii in spiritualibus ac etiam in temporalibus mensae archipraesulis Mediolani condiderim meum testamentum ac codicillos rogatum ac rogatos a M. reverendo domino Dominico Antonio Pagano curiae archipraesulis Mediolani notario, paroco Castelli et Vallysolidae vicario [...], in quo seu in quibus elegi pro administratione totius meae haereditatis plures executores testamentarios cum omnimoda facultate et auctoritate tractandi mea negotia ac si ego ipse tractarem, etiam cum iure et facultate nominandi ac praesentandi ad dictum benefitium et prout in ipso testamento seu codicillis legitur ac continetur. 
Hinc est, cum possim addere et minuere, prout mihi placuerit, donec adhuc sum compos meae mentis, nisus et intellectus, propterea aliis meis executoribus testamentariis, qui sunt: multum reverendus dominus canonicus Franciscus Ceronus, multum reverendus dominus Carolus Isidorus Affaitatus benefitiatus ecclesiae Sanctae Mariae et dominus Petrus Martyr Bellotus habitans in loco Sancti Mammettis, addo et adiungo supradictis cum eadem facultate et auctoritate etiam praedictum multum reverendum dominum Dominicum Antonium Paganum parocum Castelli et vicarium Vallissolidae, qui una cum praedictis aliis executoribus nominatis gerat mea negotia et quem oro ac precor, ut recipiat hoc onus et sit meus coexecutor testamentarius totius meae haereditatis simul cum aliis meis executoribus, etiam cum facultate substituendi alium vel plures executores ipso deficiente et decedente quia talis est mens mea ac voluntas.

In reliquis confirmavi ac confirmo omnia ea, quae in praedicto meo testamento ac codicillis praecedentibus continentur.

Et de praedictis etc.

Actum in cubiculo, ubi aegrotus iacebat praedictus dominus codicillator, sito in loco Albogasii [...] praesentibus pro testibus multum reverendo domino patre Alexandro Bonacicino filio quondam Petri, habitatore Albogasii, et Carolo Dominico Bigneta filio quondam Mammettis, habitante in loco Sancti Mammettis Vallissolidae notis et idoneis.

Et pro fide Iohannes Maria Pusterlinus notarius, nunc habitator Cressonii et Parterii, prefectus Caravinae Vallisolidae.

\section{III}

\section{Como, Archivio di Stato, Archivio Notarile, Atti dei nottai 3566, Procuratio dominorum executorum testamenti nobilis quondam domini Francisci Ceroni in dominum Ioseph Rachettum degentem in civitate Varsaviae - 21 [lub 31] Augusti 1725.}

-1725, 21 [sic] Augusti. Procuratio dominorum executorum testamenti nobilis quondam domini Francisci Ceroni in dominum Ioseph Rachettum degentem in civitate Varsaviae [...] mei, notarii Petri Vincentii Meolini quondam Ioannis Baptistae loci Casarici Vallissolidae.

In nomine Domini amen. Anno a nativitate eiusdem millesimo septingentesimo vigesimo quinto, indictione tertia, die Veneris trigesima prima [sic] Augusti.

Perillustris et magnificus reverendus dominus Franciscus Ceronus, filius quondam Hyeronimi, loci Albogasii, nunc parochus Cresonii et praepositus Beatisimae Virginis Mariae nuncupatae de Caravina Vallissolidae, et reverendus dominus Carolus Isidorus Affaitatus, filius nobilis quondam domini Dominici, pariter de dicto loco Albogasii Vallissolidae, dominii etiam in temporalibus mensae archipraesulis Mediolani, uti executores ambo testamentarii nobilis quondam domini Francisci Ceroni loci dicti Albogasii Vallissolidae, filii nobilis quondam Iacobi, iam vita functi mense 9-bris anni 1724 - pro executione piae haereditatis ab ipso relictae favore legatorum piorum - apparente ipsius testamento condito et rogato per magnificum reverendum dominum Dominicum Antonium Paganum publicum curiae archipresulis Mediolani notarium [...] sub die quarta Novembris anni praedicti et cum eis praefatus perillustris et admodum reverendus dominus Dominicus Antonius Paganus parochus loci Castelli Vallissolidae vicarius [...] uti pariter ipsius quondam domini Francisci Ceroni executor testamentarius constante codicillo eiusdem domini Ceroni facto sub eadem die 4 Novembris rogato per magnificum reverendum dominum Ioannem Mariam Pusterlinum publicum curiae archipraesulis Mediolani notarium [...] omnes tres unanimes et concordes etc.

Voluntarie etc.

Et alias omnibus modo etc. 
Constituerunt et constituunt, fecerunt et faciunt solemniterque ordinaverunt et ordinant suos certos nuncios, missos, procuratores speciales et quidquid melius etc.

Dominum Ioseph Rachettum ac dominum Carolum Bay, socerum respective referendo et generum, degentes in civitate Varsaviae, absentes tamquam praesentes, et tam unitim quam separatim, ut unus independenter $\mathrm{ab}$ alio in praemissis [...] agere valeat.

Specialiter et expresse ad - procuratorio nomine praefatorum dominorum executorum testamentariorum constituentium et pro adimpletione dictae piae haereditatis - requirendum, instandum et agendum apud et contra quaslibet personas et ab eis exigendum, recipiendum et petendum omnia et singula credita tam super mobilibus quam super immobilibus rebus ab ipsomet nobili quondam domino Francisco Cerono relicta, praecipue in dicta urbe Varsaviae ac etiam in aliis regionibus ac locis Poloniae etc.

Et signanter ac specialiter ad - procuratorio nomine, ut supra - habendum, consequendum et recuperandum a dominis Dominico et Sophia Higalibus de Combonis, degentibus in praedicta civitate Varsaviae, residuum pretium domus venditae a nobili quondam domino Carolo Cerono filio dicti nobilis quondam Iacobi et dicti domini testatoris fratre, haerede instituto ab eodem domino nobili quondam Carolo fratre, ut ex testamento eiusdem etc. cui etc. quod residuum debitum constat ex scriptura contractus venditionis domus dictae ac obligationis, facta Varsaviae et subscripta a praedictis Higalibus de Combonis et testibus sub die 14 Ianuarii anni 1722.

Item ad - procuratorio nomine, ut supra - pro eiusdem residui consecutione comparendum coram quolibet iudice competenti tam ecclesiastico quam saeculari et apud eum iuridice agendum et instandum, comparendum et dictos dominos debitores citandum ac comparere faciendum et compellendum omnemque actum et omnes actus opportunos faciendum, quantum opus fuerit, omnemque litem ac omnes lites intentandum contra dominos dictos debitores, prosequendum ac finiendum usque ad totalem expeditionem causae et crediti consecutionem.

Item ad appellandum a quacunque sententia et appellationem interponendum, quatenus et si opus fuerit ac libuerit, et de sententiae iniquitate ac iniustitia dicendum et protestandum.

Item ad - procuratorio nomine, ut supra - quoscunque calculos cum quibuscunque personis in praemissis, ut supra, et signanter cum dictis dominis de Combonis ineundos, restringendos et liquidationem ac declarationem super iis faciendam ac de receptis quamlibet confessionem pariter faciendam tam per publicam quam per privatam scripturam eamque subscribendam et confirmandam.

Item ad - procuratorio nomine, ut supra - quemlibet arbitrum ac arbitratorem, arbitros ac arbitratores in praemissis eligendum, determinandum ac quodlibet arbitramentum ac compromissum faciendum.

Item ad - procuratorio nomine, ut supra - iurandum et quodlibet opportunum iuramentum praestandum et praestare possendum, quatenus et si opus fuerit in praemissis, in anima et super animam ipsorum dominorum constituentium, prout praefati domini constituentes in praesentia mei, notarii, iuraverunt et iurant, tacto pectore, more sacerdotali.

Item ad - procuratorio nomine, ut supra, in praemissis et non aliter - substituendum unum vel plures procuratores, prout opus fuerit.

Item ad - procuratorio nomine, ut supra - in praemissis faciendum et facere possendum ea omnia et singula, quae facerent et facere possent praedicti domini constituentes, si praesentes essent, etiamsi talia forent, quae mandatum magis speciale requirerent.

Quare etc.

Dantes et volentes etc.

Cum plena et libera etc.

Promittentes etc.

Quae omnia cum pactis executivis etc.

Insuper iuraverunt tacto habere ratum non contravenire sub [...] etc.

Et de praedictis etc. 
Actum in sala domus habitae dominorum haeredum nobilis quondam domini Dominici de Affaitatii praesentibus domino doctore physico Ioseph Antonio filio quondam domini Dominici Affaitati, domino Arnoldo Lepeno quondam Caroli, Ioseph Cerono quondam Iacobi, Dominico Putino quondam Iacobi, omnibus dicti loci Albogasii, et domino Hieronymo Bellotto filio domini Caroli Antonii loci Sancti Mammettis Vallissolidae testibus notis, idoneis et vocatis.

\title{
IV
}

\section{Warszawa, Archiwum Główne Akt Dawnych, Nabytki Oddziału III, sygn. 31 Korespondencja Carla Ceroniego z Samuelem Paczowskim ekonomem i administratorem dóbr wojewody płockiego Jana Dobrogosta Krasińskiego}

\author{
1.
}

\section{Mości [Do]brodzieju}

Odebrałem list WMCIPana w którym pytasz, mnie WMci Pan jeżeli P. Baj kamienie sprowadził do galeryi OO Reformatów potrzebne ja teli[?] donoszę że sprowadził więc pośle WMPanu podwody po nie gdyż ja nie mogę kazać zawieść WMciPanu końmi memi gdyż mam gwałtowną potrzebę koni moich. Co zaś strony Maćka Kamieniarza ten żadną żywą miarą nie chce jechać do WMPana, ale ja będę mówił Panu Baij jeżeli on swego człeka nie może posłać do roboty. Co doniósłszy[?] WMPanu kończę list mój żem jest WMPana i dobrodzieja szczerze życzliwy i niski sługa

Carlo Ceroni

Warsavia 3 maj 1715

Mości Dobrodzieju

Odebrałem list od WMciPana w którym mi piszesz WMci Pan dowiadując się jak wiele trzeba podwód do kamieni zwiezienia. Teraz jeszcze nie podobna abym WMPana w tym mógł informować gdyż jeszcze nie są wszystkie ociosane i wyrżnięte, ale jak będą zakończone to WMści Panu oznajmię, to także donoszę że trzeba kamiennika do stawienia kamieni gdyż Dominik nie poradzi temu. Co zaś strony skończenia wszystkich rzeczy potrzebnych o których mi WMPan piszesz będę ja pisał do Dominika aby się starał jak najprędzej koło tego zakrzątnąc i ja tam sam wkrótce przyjadę. Proszę teraz WMPana o te łaskę abyś kazał przywieźć piasku z Ady[?] gdyż ten jest najlepszy do fabryk aby gzyms mógł skończyć tymże piaskiem który WMci Pan z łaski swojej każ przywieść. O co pokornie upraszając kończe list mój żem jest WMci Pana i Dobrodzieja mego szczerze życzliwy sługa. Carlo Ceroni

W Warszawie 10 maja 1715

Monsieur

Przy oddaniu uniżoności mojej WMPanu i Dobrodziejowi dowiaduje się o miłym zdrowiu WMPana oraz donoszę żem jest w różnych myślach nie wiedząc jeżeliś WMPan oddał Dominikowi te trzysta tymfów. Jeżeli WMPan nie oddał suplikuje pokornie żebyś WMPan oddał jak najprędzej odsłużę te także WMPanu i Dobrodziejowi memu kom pisał do Dominika żeby mi za te pieniądze kupił niektóre rzeczy rad bym zastał jak tam przyjadę bo się wybieram takoż za Bożą 
pomocą będę tam wkrótce u WMPana dlatego suplikuje powtórnie żebyś WMPan dał te trzysta tymfów także w regestra zajrzał żebyśmy w porachowaniu się ze sobą czasu wiele nie trawili bo sam nie myślę długo u WMPana bawić. Posyłam także do WMPana koni moich parę suplikując pokornie abyś ich WMPan na łąki kazał puścić ze swemi ale proszę żeby niemi nie robili bo dość mieli za swe ze to fabryk trzeba żeby sobie na łąkach wypoczęły teraz. Za te także WMPanu i Dobrodziejowi memu odsłużę w czym mnie rozkaz WMPna znajdzie czyli żelaza WMPan będzie potrzebował czyli czego proszę podufale rozkazać sobie a ja z ochotą będę służył WMPanu to donosiwszy kończę zaleciwszy się w łaskę i affekt WMPana jako ten który jest WMPana i Dobrodzieja szczero życzliwy i najniższy sługa

Varsa[via] 9 8bris 1716

Carlo Ceroni

4.

Monsieur

Vars[avia] 19 Augu[sti] 1717

Dziwno mi że WMPan piszesz do mnie taki list wiedząc dobrze co ja za szkodę miał budując i burząc, co JWMPan Wojewoda ś. p. obiecał mi kompensować, a dotychczas nic nie widzę. Suplikuje tedy pokornie do łaski WMPana abyś mnie w swej łasce miał i protekcyi, i u WMPani Starościny wyjednał to abym pieniądze moje odebrał, a ja obliguje się tam jechać dla skończenia tylko niech mam pierwy co mi należy bo jest wielce potrzebne. Że zaś zacieka u oo. Reformatów jam temu nic nie krzyw już to kilka lat jak ja fabrykę skończył. Ufam tedy w łasce WMPana że mnie w protekcji swojej mieć będziesz a ja i Dominika poślę tylko niech odbierze pierwy swoje. To wyraziwszy zapewniam zem jest

De votre Monsieur

le tres humble et tres obeisant serviteur

Carlo Ceroni

5.

Monsieur

$\operatorname{Var}[$ savia] 107 bris 1717

Jam kilka razy pisał do WMPana upraszając WMPana abyś mi posłał regestr co mi jeszcze należy od WMPaństwa a nie mogę tej łaski otrzymać od WMPana. Piszesz mi WMPan, że nic nie wezmę póki nie skończę wszystkiego u oo. Reformatów, czyli to nie jest wiadomo WMPanu, że ja wszystko dawno już zakończył i jak wiele w tym miałem szkody murując i burząc, a o tym nic WMPan nie wspomnisz, ja się nie wymawiam jechać i upewniam, że pojadę ale pierwy chce być upewniony, że zastanę pieniądze mnie należące złożone u OO Reformatów. Proszę mój Dobrodzieju miejże mnie WMPan w łasce swej abym bez trudności mógł swoje odebrać a ja za te łaskę odsługować WMPana będę jako ten który jestem WMPana i Dobrodzieja najniższym i szczerze życzliwym sługą

Carlo Ceroni

P.S. Oznajmij mi WMPan jak pieniądze dla mnie gotowe będą a ja zaraz odebrawszy tę wiadomość od WMPana przyjadę do WMPaństwa skończyć to wszystko co WMPaństwo pretendować będą.

6.

Monsieur

Na tak wiele listów moich którem do WMciPana pisał żadnego dotychczas nie odbieram responsu, na co wielce ubolewam wiedząc dobrze żem się nie zasłużył na taką niełaskę WM Pana. Nie wiem czyli to nie doszły listy moje WMCiPana czyli też WMCiPan polityką mnie chcesz zbyć. Wiem dobrze o delikatnym sumieniu WMPana dlatego reprezentuje przed WMPanem to co 
WMPanu jest dobrze wiadomo. WMCiPan piszesz mi żem nie dokończył fabryki tak u OO. Reformatów jako też i u fary, co nie wiem w czym bym takim nie dokończył jeżeli w oknach żem do wszystkich żelaza nie dał. Każ się WMCiPan spytać jeżeli to nie wszędy tak jest jakom ja tam dał. A i u Ojców Kapucynów tylko u jednego okna są zawiasy, ale i to niczego, ja i to się podejmuje naprawić, ale mnie WMCi Pan pierwej uspokoić staraj się, wszak WMciPan wiesz że mi należy za ostatnią ratę 1620 złotych, od wykopywania piasku 500 złotych przez lat sześć. Niech to pierwy odbiorę nie będę skromnym dokończyć i sporządzić co mi WPaństwo rozkażecie. Już ci suplikowałem pokornie już i nie raz prosiłem abyś WMPan miał mnie w łasce swej i miał starannie uspokoić mnie. Teraz z wielkiej potrzeby w której się wynajduje obliguje WMPana na sumienie abyś mnie w tym ratował Wszak WM Pan wiesz iż to jest grzech śmiertelny rzemieślnikom zatrzymać powinne swoje zapłaty. I ja tak rozumiem, że JMWPan Dobrodziej ś.p. dla zatrzymania tego mego cierpieć będzie w czyśćcu i póty póki mnie WMPaństwo nie uspokoicie. Wierzę WMCiPan jakoś za żywota był życzliwy Panu swemu tak i teraz miej pożałowanie nad nim i nad duszą jego, a mnie uspokoić staraj się WMCiPan gdyż te funkcje które WMPaństwo czynicie nie będą taką pomocą duszy Jego jako to kiej WMPaństwo oddacie co komu należy, gdyż ci co im należy wcale, że pomsty do Boga wołają. Zaś jakem był życzliwy Sługa JMci Dobrodziejowi ś.p. za żywota tak i teraz jestem i dlatego dotychczas anim wołał pomsty ani wołam ale się obawiam aby mnie ciężka potrzeba do tego nie stymulowała. Suplikuje pokornie przeczytać ten list mój dobrze i zrozumieć go a wiem, że się WMPan uratujesz nad duszą Pana swego ś.p. i nad potrzebą moją. Oczekuje tedy łaski WMPana i proszę abyś mi WMPan jeżeli nie wszystko to przynajmniej cokolwiek przesłał przez tego ogrodnika ale upominam WMPana że Pan Bóg WMCJ Panu za ten miłościwy uczynek nagrodzi i ja odsłuże WMci Panu w czym tylko czeka mnie WMPana[?]

To wyraziwszy kończę żem jest

De votre Monsieur le tres humble et tres obeisant serviteur

Varsaviae 217 bris 1717

Carlo Ceroni 


\section{Carlo and Francesco Ceroni in the Light of New Archival Sources}

In the second half of the $17^{\text {th }}$ centurym a group of architects from Valsolda on Lake Lugano, northern Lombardy, came to Warsaw. Among them there were Carlo and Francesco Ceroni. These architects thanks to the investigation conducted by Prof. Mariusz Karpowicz have had their respective studies published. It was Prof. Karpowicz who found their birth certificates in the Albogasio Inferiore Parish Archives, ascertained their family ties, found Francesco Ceroni's contract for the works on the church of the Nuns of Perpetual Adoration of the Blessed Sacrament, as well as Carlo Ceroni's last will. The research performed by the author of the paper for the Dictionary of the Architects and Stonemasons in Warsaw in the $15^{\text {th }}-18^{\text {th }}$ Centuries brought about a number of biographic data. The preliminary research in the Albogasio Inferiore Parish Archives revealed some source documents. Among the discovered ones there was Ceroni's authorization given in 1711 to the Bellottis: Pietro Martiri and Carlo Antonio in the presence of the Municipality of Old Warsaw to represent him in contacts with the authorities of Valsolda, as well as a set of documents related to the financial conflict between Carlo Ceroni and Carlo Farina. The clash made Ceroni exclude the Farina family from his inheritance. Farina who secured the architect's interests in Italy in 1693-99, accused Ceroni of not having repaid the whole of his debt. In a letter from
Warsaw dated 16 May 1714 addressed to his cousin, Mayor of Valsolda, Ceroni submitted arguments demonstrating that not only had he repaid the debt, but had even suffered financial losses through the shared business with Carlo Farina. The very same letter reveals that the architect's second daughter Lucia, contrary to the to-date ascertainment, lived to come of age and aged 31 became a nun (d. 1717). The preliminary research in the Como Notarial State Archives allowed to find Francesco Ceroni's codicil and authorization issued by Ceroni's heirs to Carlo Antonio Bay and Giuseppe Rachetti to recover debts from Zofia and Dominik Comboni.

Six letters of Carlo Ceroni to Samuel Pączkowski, administrator of the Krasiński estate discovered in the Central Archives of Historical Records in Warsaw, brought new information on the works conducted in Węgrów. The letters make us verify how long the works on the church and convent complex of the Węgrów Reformati lasted, and prolong them by at least ten years.

The analysed sources permit the claim that it was the junior of the Ceroni brothers, namely Francesco, who owned the building enterprise. Carlo and Francesco Ceroni managed to amass substantial wealth which following their death became the property of the residents of Albogasio as the Eredita Ceroni. Still in the $19^{\text {th }}$ century, its yields were allocated to satisfy their needs. 
